\title{
導電性ファブリックを用いた全身被覆型触覚センサスーツ
}

\author{
稲 葉 雅 幸* 星 野 由紀子* 井上 博 允*
}

\section{A Full-Body Tactile Sensor Suit Using Electrically Conductive Fabric}

\author{
Masayuki Inaba*, Yukiko Hoshino* and Hirochika Inoue*
}

\begin{abstract}
We present design and implementation of a tactile sensor system, sensor suit, that covers the entire body of a robot. The sensor suit is designed to be soft and flexible and to have a large number of sensing regions by using electrically conductive fabric and string. The whole signals from the sensor suit are superimposed on a visual image of the robot. The construction of sensor suit with 160 sensing elements for a full-body humanoid and the experimental results to evaluate electrically conductive fabric and the tactile sensing unit are described.
\end{abstract}

Key Words: Tactile Sensor, Sensor Suit, Electrically Conductive Fabric, Humanoid, Sensor-based Behavior

\section{1.はじめに}

触覚センサの高性能化，高密度化とともに，ロボットの全身 に触覚エレメントを分布させる技術は, 人間の生活空間に入り 込むことが求められている将来のロボットにとって必要不可欠 な基盤技術である．多くの関節をもつロボットの全身に触覚セ ンサを分布させるには，関節の動きを妨げないような触覚エレ メントの構造と, 多数の配線を行う方式が課題となる.

現在までに行われている触覚エレメントには，感圧導 電性ゴムを使った触覚センサ[1], 圧電効果を持っ PVDF (Polyvincylidene Fluoride) フィルムを用い力覚情報とすべ り覚情報を得るセンサ [2], 超音波を用いたもの [3], 静電容量 の変化を見るもの [4]，メカニカルスイッチを用いたもの [5]，な どがある。これらは主に指部やハンド部用に考えられたものが 多く，ロボット全体に分布させた例は少ないが。近接センサを ロボットアーム全体に分布させた例 [6]や，曲がることを考㥁 して関節部用の接触センサを考えた例 [7]がある.

しかし，現状では，各センサの機能面では力覚やすべり覚の 検出など多様な研究がなされているが，触覚エレメント自体が 柔らかく全身を網羅できる構造を持つものがない。そこで，本 研究ではロボットの全身に触覚を分布させるセンサシステムを 開発することを目的とし，素材として布に着目し，どのような 形状・構造のロボットに対しても，全身を覆うことができるセ ンサスーツの構成法を提案し評価することを行う.

原稿受付 1996 年 12 月 6 日

*東京大学工学部機械情報工学科

*Dept. of Mechano-Informatics, The University of Tokyo

\section{2. 全身被不型ロボットセンサスーツの設計方針}

全身を覆う触覚センサの実現課題と設計方針を以下にまと める。

（1）変形可能で衝慗などに対して破壊しにくいセンサユニット 全身に分布させるセンサユニットは変形容易な構造とし, 衝撃力が加わった場合にも破壊しないような材質の部品 を用いる必要がある，そこで，人間の全身を覆う衣服の ように，糸が織られてできあがっている布構造に着目し， 系や布に導電性を与えた導電性ファブリックと非導電性 のネットと布の積層によって触覚エレメントを実現し， 衣服構造を構成することで全身に触覚を分布させる構成 法を実現する。

（2）柔らかさを損なわない大量の配線法

センサエレメントを多数分布させる場合の大きな課題は 大量の配線方法である. 固い配線の束を作った場合には, 関節部の運動を妨げてしまうことになる。パラレル配線 をシリアル伝送にする処理ユニットを分布させる方法が 考えられるが，全身に面状に分布しているセンサシステ ムには適さない。ここでは，重ね合わせが容易な布を利 用し，導電性の糸を面状に分布させた配線層を設けるこ とで大量配線に対処する。

（3）多量センサの計算機へのインタフェース センサユニットからの大量の配線を計算機に直接接続し ようとすれば, 計算機に多数の入力ポートが必要となる が，そのような計算機を専用に開発していたのでは，七 ンサユニットの数や配置の変更に対する対処が困難にな る。そこで，大量なセンサ情報を規格化された画像信号 
に多重化し，その画像信号用の処理システムを用いる方 式をとる。これにより，既存の並列画像処理システムも 使うことができ，また，マッピング方法を工夫すること により，人が見ても分かりやすい形にすることができる。 (4) 修理・改造への対応性

触覚センサに基づいた行動を行うロボットの大きな課題 として，センサ自体が破損しにくいことだけでなく，ボ ディ自体の修復・取り替え作業が容易であることがあげ られる。そこで，分布させたセンサと配線を一体とし， ボディの外側を被覆する形とすることで，着せ替え可能 な構造とする。これにより，ロボット本体内部の修理を 容易とし，試作・実験を絽り返した結果によって，その ロボットの動きに適したセンサスーツを順次制作してい くことも可能である.

3. 挲電性ファブリックを用いたセンサスーツの実現

3.1 道電性ファブリックによる柔構造センサュニット の実現

導電性ファブリックとは，通常の布に導電性をもつような加 工を施したもののことである．布を導電性にするには，導電性 塗料を布に塗ったり，印刷したりする方法が考えられるが，布 全体に均質性を保ち，折れ曲がっても剥がれることのないよう にするためには，布の表面に付着する金属材料が薄く，かつ布 の微細峨維表面にまで入り込む加工法が必要となる。そこで, 本研究では化学メッキによって樴維の内部まで均質にかつ薄く 金属を付着させて作られた導電性ファブリックを用いる。

触覚センサユニット部はFig. 1 のように 5 層構造となる。第 1 層は，一番外側の布である。普通の布を用いており，配線層 の保護と配線の系のショート防止のためにつけられている。第 2 層は, 配線層である。ここでは, 導電性の系で普通の非導電 性の布を縋うことで配線を行っている。 スイッチ部との接続は, 導電性の系で，導電性の布を縫うことで実現している，第 3 層 は，スイッチ端子層であり，導電性の布を欲しいエリアごとに

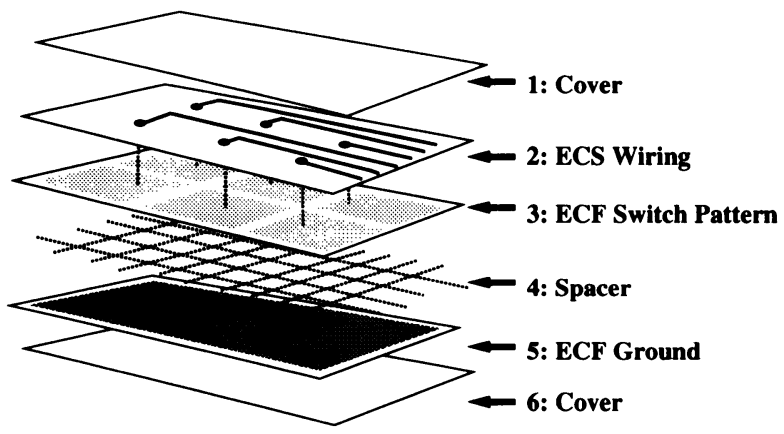

1: Cover $\rightarrow$ a cloth for protection 2: Wiring $->$ sewing a cloth with an ECS

3: Switch Pattern $\rightarrow$ distributed segments of ECF

4: Spacer $\rightarrow$ reticulate structure (net)

5: Ground -> a cloth of ECF

6: Cover $->$ a cloth for protection

Fig. 1 Layered structure of the tactile sensor units
わけてミシンで非導電性の布に䋖いつけている。ここで，ス イッチの密度や配置が決定される，第 4 層は，スイッチ端子間 のスペーサである。この部分のスペーサにはネットを用いてお り，この厚さ，穴の大きさなどで, スイッチの接触感度がかわ る。第 5 層は，接地端子層である。こちらは導電性の布が大き く 1 枚で非導電性の布に縫いつけられており, かつ導電性系で 第 2 層の配線層に接続され接地されている．この第 5 層と第 3 層が圧力を受けネットの編み目の間で接触すると、スイッチの 役割を果し, 回路が閉じて電流が流れ，接触していることを表 すようになっている。

\section{2 スーツへの展開と製作手順}

様々な体型を持つロボットの全身に柔軟にフィットさせる方 法として，人間に対すると同様に，洋服を仕立てる形で製作す る. 手順は, 型紙を作り, 仮縫いで調整し, ミシンで仕立てる ことになる。このときに，前述の第 3 層にあたる部分を，必要 に応じた大きさの接触領域毎に分割することで，全身に対して センサを分布させることができる.

Fig. 2 にセンサスーツのレイア構成を示す. 基本構造に示 すように 5 層のレイアから成り立っている，前身頃，後ろ身 頃，そでの各左右の 6 部位に分かれており，製作する際には各 部位ごとにレイアを積層して加工した後全体を縫い合わせる

(Fig. 3).

（1）型紙を用いて布を裁つ。センサースーツ1着について, 非導電性布を 4 組, 導電性の布を 2 組, スペーサ用の ネットを 1 組用意する。また，配線を引き出すための帯 状の長方形の布を，配線を縫いつける布とそれの表裏を カバーして保護する布の 1 組 3 枚として， 8 組用意する.

（2）非導電性の布に導電性の布を縫いつける.ジグザグミシ ンでまわりを桻う。このときに，前述の第 3 層にあたる 部分の導電性布は接触領域毎に布を裁ちそれぞれ各領域 ごとに䋖いつけ，第 5 層に当たる部分は，そのまま大き く 1 枚綎いつける。

（3）韭導電性の布に導電性の系をぬいつけて配線を行う。隣 の系と接触してショートしないように注意する．配線の

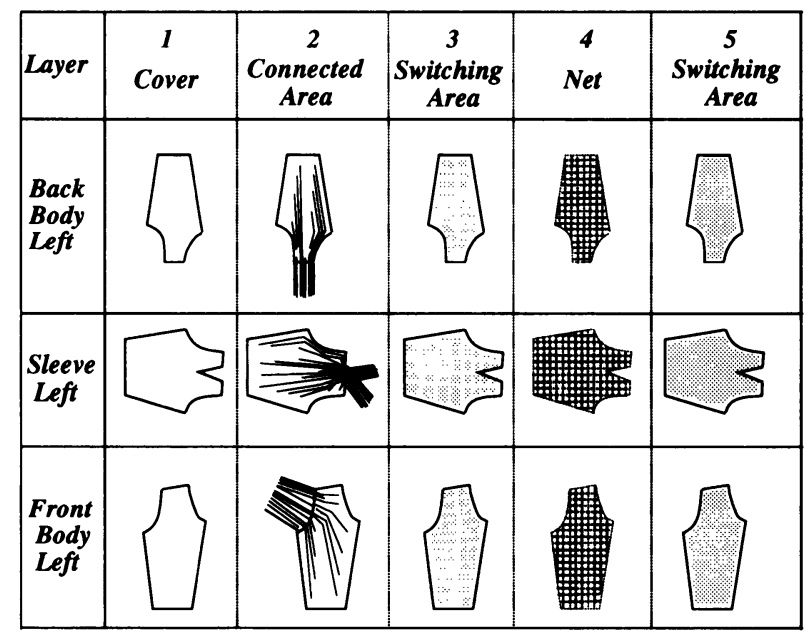

Fig. 2 Layers of each sections of a sensor suit 
(1)

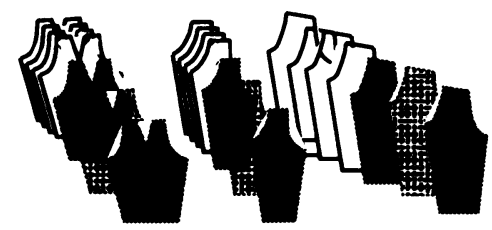

(2)

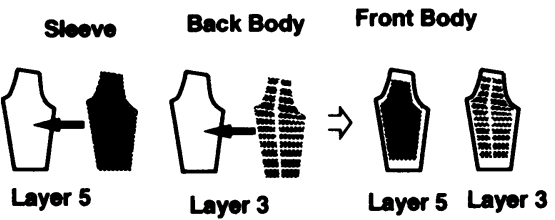

(3)

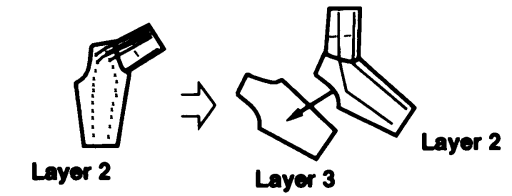

(4)

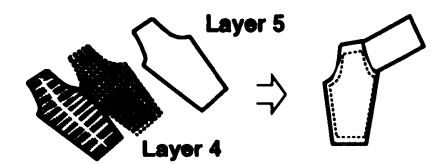

Layor 2,3

(5)

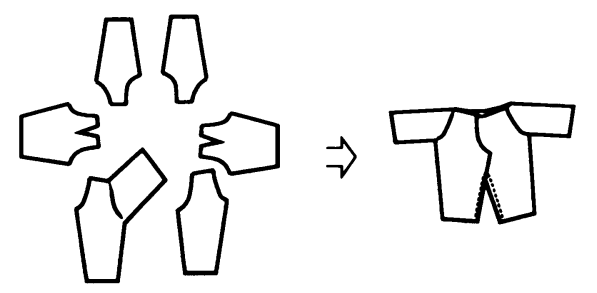

Fig. 3 Procedure to assemble parts of a sensor suit

画端の系は長めに残しておき，その一方は第 3 層の導電 性布に䋖うことで接続する。

（4）第 2，3 層を重ね合わせた物とスペーサである第 4 層を 重ねる。そそこに，第 5 層を重ね，まわりを縫う。第 5 層 と配線部第 2 層を結ぶささらに, 配線部保護の第 1 層を 重ね，再び周りを䋖い，配線の引き出し部として帯状に 出していた部分も保礼のために上下に布を縫い合わせる.

（5）前身頃，後乃身頃，そでのそれぞれ左右について以上の 手順で製作し，各部位を䋃いあわせ，全体の形をつくる.

（6）配線のためのスナップをつけ, 導電性の系で数回スナッ プを䋖って接続する. 反対側のスナップには, 線を半田 付けする。.これにより, 普通の電子回路と接続できるよ うになる。

以上で，センサスーツ本体は完成である.

\section{4. 道電性ファブリックの特性評価}

\section{1 メッキ処理による夏電性ファブリック}

本研究で利用した導電性布と系は，メッキ加工によって布に 導電性を与えたものである。メッキ加工には，電気メッキ，化 学メッキがあるが, 布全体への均質さを保つために, 化学メッ キによって作られている．布の材質はポリエステルで織り方の 䢰いによって各種物理的特性が変わる，導電性系はアラミド樴

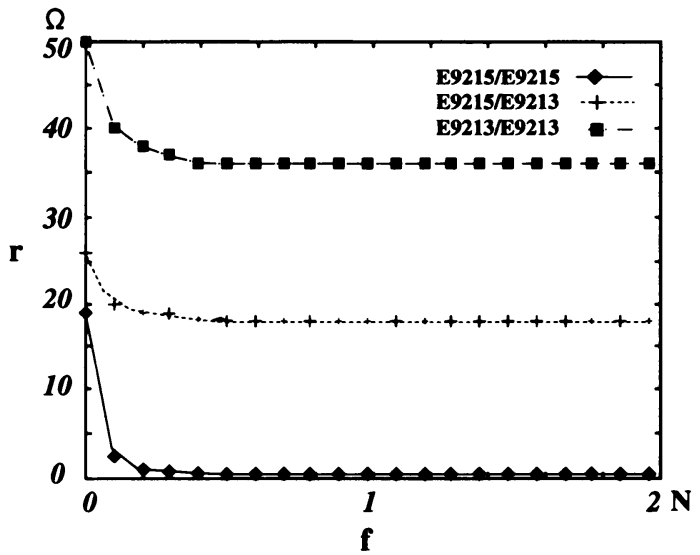

Fig. 4 Resistance between two ECFs in applying force [r: resistance $\mathrm{f}$ : applied force]

維 40 双糸をメッキしたものである.

メッキに用いる金属は, 亜鉛, 銀, ニッケル，銅などを利用 できる．金属の選定には，さびにくさを考慮する必要がある． また，電位差のある異なる金属同士を接触させた場合の腐食現 象である電蝕効果も考虑しなければならない，ここでは，比較 的電蝕の影響の少ない銅とニッケルをメッキしたものを用いる。

メッキ付着量が異なることによって特性の違う, E9215（銅： $15\left[\mathrm{~g} / \mathrm{m}^{2}\right]$, ニッケル: $7\left[\mathrm{~g} / \mathrm{m}^{2}\right]$, しゅす織り), E9213 (ニッケ ル:7 $\left[\mathrm{g} / \mathrm{m}^{2}\right]$, 平織り) の 2 種類（神東塗料ケミトロン製）を, 折り曲げ, 湿度などの観点から実験評価し, センサスーツに適 した材質のものを選ぶことを行った。

\section{2 圧力による接触抵抗值の変化}

本センサユニットは，導電性ファブリック間の接触によって On/Off の導通判定をする形になっているが，導電性ファブリッ クを 2 枚重ねたときにそこに加わる圧力によって接触抵抗が変 化するため，ネット層を置かずに直接接触させた場合の特性を 調べる。

2 枚の $5[\mathrm{~cm}]$ 四方の導電性ファブリックを試験片として用い, おのおのが $1[\mathrm{~cm}]$ の幅で重なるように配置し，その重なってい る部分の上に $5\left[\mathrm{~cm}^{2}\right]$ の板をのせそこに分銅を載せるという方 法で調べた．試験片の組み合わせは，1）E9215 と E9215，2） E9215 と E9213，3）E9213 と E9213の 3 種類を用意する。

結果はFig.4である. 接触力としては十分小さな値で, 2 枚 のファブリックが安定して導通することが分かる.

また, ヒステリシスの有無に関しての害験も行ったが, 加圧 時と減圧時においてまったく同じ抵抗変化を示した。

\section{3 曲げやこすりに対する耐久性}

全身に分布させるために, 时などの屈曲部では折り曲げやこ すりが起こると考えられる，そこで，折り曲げやこすりに対す る酎久性を調べた，折り曲げ動作やこすり動作に対する耐久性 を調べるために試験片として，A）導電性ファブリック E9213， B） E9215，C）アラミド䄉維 40 双系単体，D）系を布に縫い つけた物を用意した．布は $5[\mathrm{~cm}]$ 四方に切ったものを，系は $10[\mathrm{~cm}]$ の長さに切ったものを用意する．それらを，合計 1,000 回, 1) 曲率半径約 1.25 [mm], 布の横采方向に繰り返し曲げ伸 


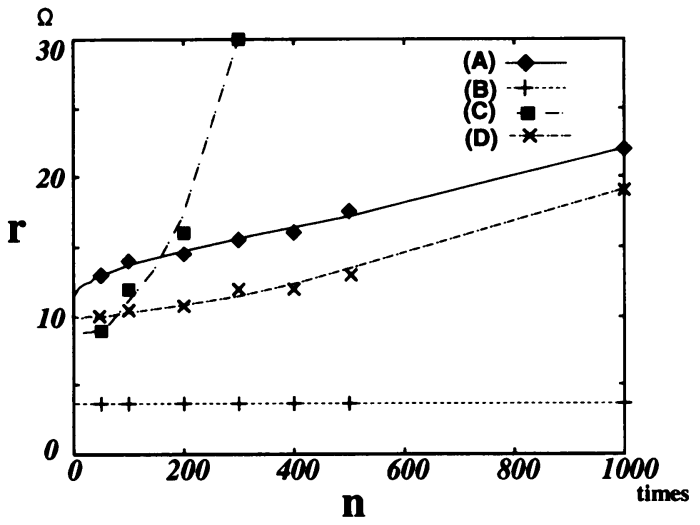

Fig. 5 Durability Experiment (1): repeating fold and unfold [r: resistance $\mathrm{n}$ : repeating times]

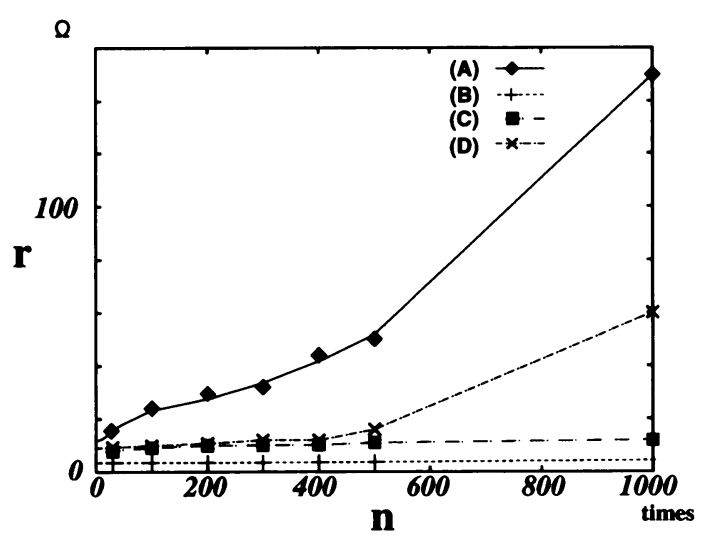

Fig. 6 Durability Experiment (2): rubbing each other [r: resistance $n$ : repeating times]

ばした後と，2）水平速度約 $1.3[\mathrm{~m} / \mathrm{s}]$, 周期䄪 $4[\mathrm{~Hz}]$, 垂直荷

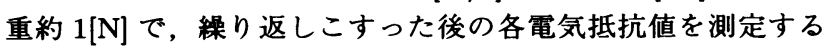
実験を行った。また, 系は, 単体のほか, 非導電性の布に縫い つけた状態のものも実験した．実際のセンサスーツ内での状態 を考慮したためである，系はその両端にテス夕端子を当て電気 抵抗値を測定する．布は対向する 2 辺の各辺を金属クリップで はさみ，このクリップにテスタ端子を当てて電気抵抗値を測定 した。

結果の電気抵抗値は，それぞれ，Fig.5，6のようになった。

(1) 曲げ伸ばし実験

B）については，1,000 回のテストではまったく変化し なかった，よって素材として非常に適しているといえる. また，C）は，400回付近で断線してしまったが，D）の ように布に縫い込む形にすれば使用可能であると考えら れる.A）についても 1,000 回の折り曲げに関しては使 用に耐えうるだけの耐久性を持つと考えられる。

(2)こすり実験

E9213はこすりに対して抵抗変化が大きいことが分か る。しかし，E9215 はこすりに対し十分な耐久性を持つ と評価できる，本実験に用いた系に関しては，こすりに 対してやや抵抗変化が見られ保護する必要があると考え

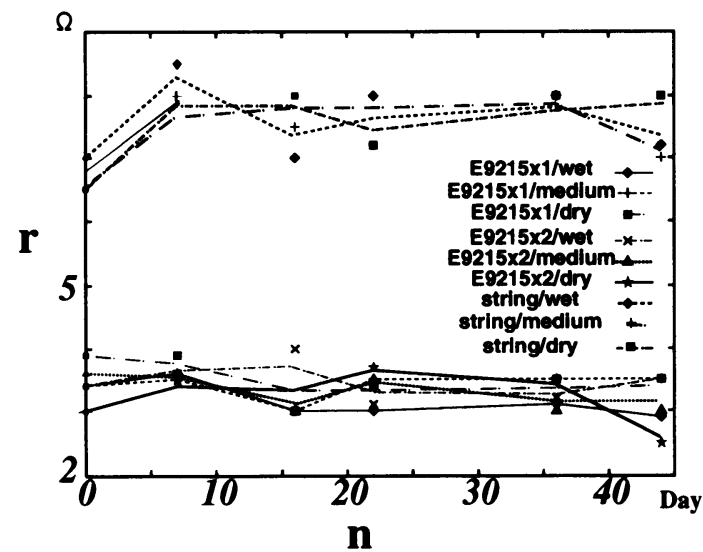

Fig. 7 Humidity test in wet, midium, dry cases of ECF and ECS [r: resistance $n$ : passing days]

Table 1 Sample net for sensitivity check

\begin{tabular}{|c||c|c|c|}
\hline $\begin{array}{c}\text { net } \\
\text { sample }\end{array}$ & $\begin{array}{c}\text { thickness } \\
{[\mathrm{mm}]}\end{array}$ & $\begin{array}{c}\text { hole size } \\
{[\mathrm{mm} \times \mathrm{mm}]}\end{array}$ & feature \\
\hline \hline 1 & 0.45 & $2.3 \times 4.35$ & cotton, oval hole \\
\hline 2 & 0.15 & $1.45 \times 1.45$ & nylon, circular hole \\
\hline 3 & 0.1 & $1.25 \times 1.25$ & nylon, hexagonal hole \\
\hline
\end{tabular}

られるが,ここで提案している積層型センサユニット構 造とすれば問題はない。

\section{4 湿度に対する耐久性}

導電性ファブリックと導電性の系の湿度に対する耐久性とし て電気抵抗値の変化を調べた。導電性ファブリック E9215を $5[\mathrm{~cm}]$ 四方に切る。 また, 導電性系は $10[\mathrm{~cm}]$ の長さに切る。 そ れらを試験片とする，a）導電性布を 1 枚，b）導電性布を 2 枚 重ねたもの，c）導電性系を 1 本の 3 種類の試験片をそれぞれ 密閉容器に入れ，人が普通に生活する環境下での乾燥や湿度に 関して調べるために，1）飽和蒸気圧の状態のもの，2）室内と 同じ状態のもの，3）乾燥骫を入れるもの，の 3 種類の環境で 一定期間放置した。

結果は Fig.7 のようになった。これによると，ほとんど劣 化が起こっていないことが分かり, 湿気の有無は影響していな いと言える。これはニッケルにより酸化しにくくしてあるため である．またこの実験期間だけでなく半年後においても，室内 と同じ状態では酸化による劣化は起こっていない.

\section{5.スペーサ選択による感度設計}

本センサユニットの実現法においては, メッシュ状のスペー サによって感度を変えることができる，スペーサの違いによる センサの基本構造の感度の傾向を調べるために何種類かのネッ トを用いて圧力と抵抗の関係を調べた。

導電性ファブリック 2 枚の間にネットをはさみ，ある一点を ランダムに選び, 弾性体で力を加えて抵抗值の変化を見る. 押 す弾性体は，指に似てかつ再現性のあるものとして，プラス チックゴム（トンボ MONO PE-01A）を直径 $6.6[\mathrm{~mm}]$ の半球 状に加工して使用した。 また，ネットは，Table 1 に示すもの を用いた，力の測定範囲は使用したはかりにより，5.39[N] ま 

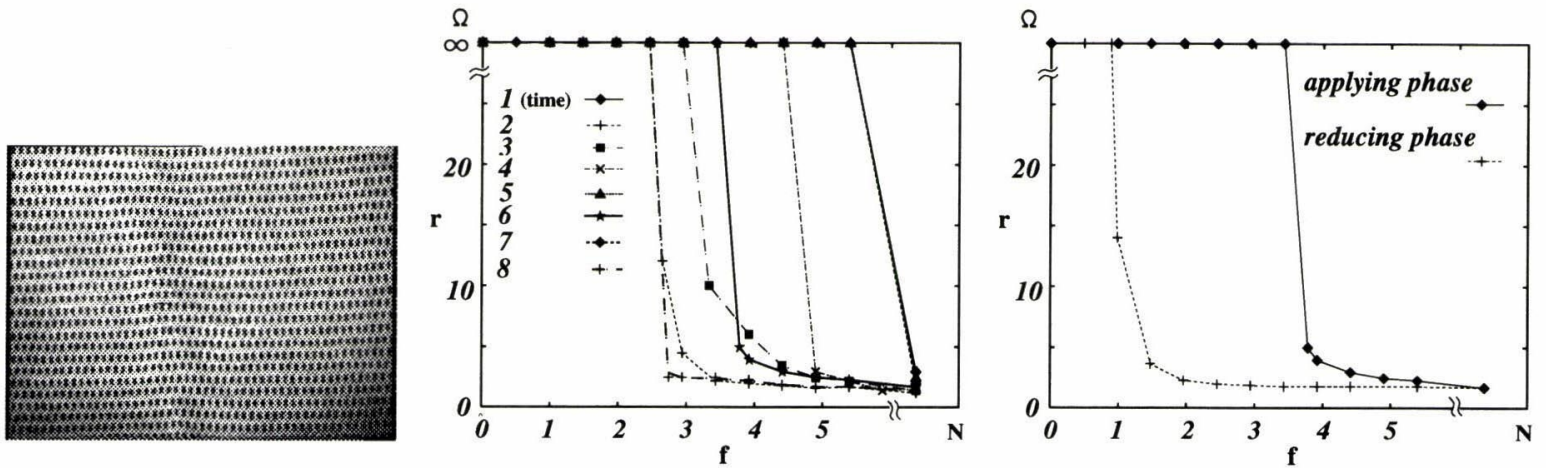

(a) Net Sample 1
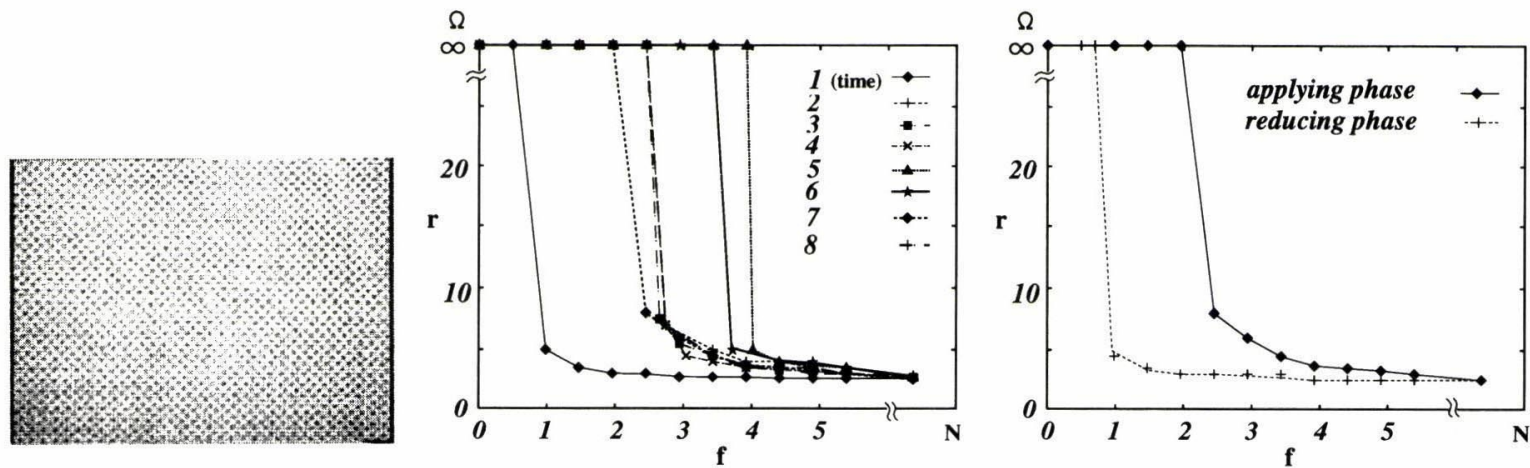

(b) Net Sample 2
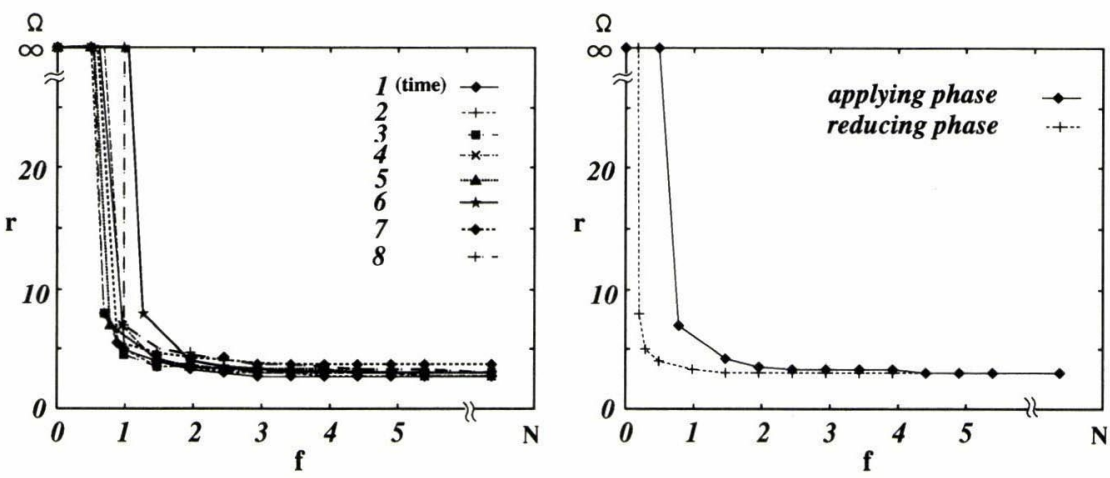

(c) Net Sample 3

Fig. 8 Sensitivity test of three sensor units (left) the image of each sample, (Center) relation between resistance and applied force, (right) hysteresis loop [r: resistance f: force]

でとした。

結果を Fig. 8 に示す.ネットの穴の大きさと穴以外の部分 の幅およびネットの厚みに対して, 押す弾性体の変形能との 関係で, 感度自体の変化と押す場所によるばらつきが出る，1 番目のネットは, 穴の大きさも穴の間隔も大きいので, 場所に よって值にばらつきが出た． 2 番目のネットは, ばらつきが出 たが， 1 番目のネットよりも低い力で反応する． 3 番目のネッ トは，もっともよい感度だった．薄いことと穴の占める部分が 大きいことから小さな力にも敏感に反応する. 感度のよさや, ばらつきの少なさから，3がよいことが分かる．また，1もば らつきに注意すれば使用できると考えられる。ただし，ロボッ 卜自身に着用させる場合はある程度の不感帯が要求される場合
もあり，用途に応じて選択すればよい。

さらに, 人の指で押す場合は, ネットの固有の性質に加え, 指による変形も ON/OFF の重要なファク夕となる。指は，加 なり柔軟であり，ネットのすきまに合わせて変形することも可 能だからである.よって，人とのインタラクションにこのセン サユニットを用いる場合には，ここでの数値よりもかなり小さ い值で導通する傾向にある．指の場合は押し方によっても，か なり大きく感度が変化する。

また, Fig. 8 右に各ネットを用いたセンサユニットのヒステ リシス特性を示す。これは, 数回の試行のなかの最も平均的な グラフをとったものである. グラフからも分かるように，どの ネットを用いたセンサユニットでも，加圧時にセンサが ONに 
なるよりも，減圧時にセンサが OFF になるほうが力が少ない ことが分かる.グラフより減圧時に明らかに OFFになってお り，ON/OFF スイッチとして利用できる。

また，触覚ユニットのサイズを変えることで空間分解能を変 えることが可能であり，スペーサとなるメッシュの厚みと穴サ イズを適宜選ぶことで接触感度を変えることも可能 [8] となっ ており，場所によって感度を変えるために異なるメッシュを用 いることも有効になる。このように用途に応じた設計が可能な 枠組であるところにも特長がある.

\section{6. 人間型ロボットにおける着用実験}

\section{1 センサスーツの構成}

人間のそばで人間との直接の触れ合いをもつロボットとして, 子供型の人間型ロボット [9]（体長 $68[\mathrm{~cm}]$, 肩幅 $36.5[\mathrm{~cm}]$, 体 重約 $6.6[\mathrm{~kg}]$ ）を対象として, ジャンプスーツ形式のセンサスー ツを仕立てた，全身に分布した情報を得るため, 全体で 160 領 域の接触状態を独立してとれるように触覚エレメントを分布し た. その構成は, Fig.9 に示すように, 身頃部分に各 8 ずつ, 足の部分に 16 ずつ，そでの部分に 16 ずつとなっている. ス ペーサ用のネットには感度しきい值の高いサンプル 1 (Fig. 8) のものを用いた.

配線は左右前身頃加各 24 , 左右後乃身頃から各 24 , 左右
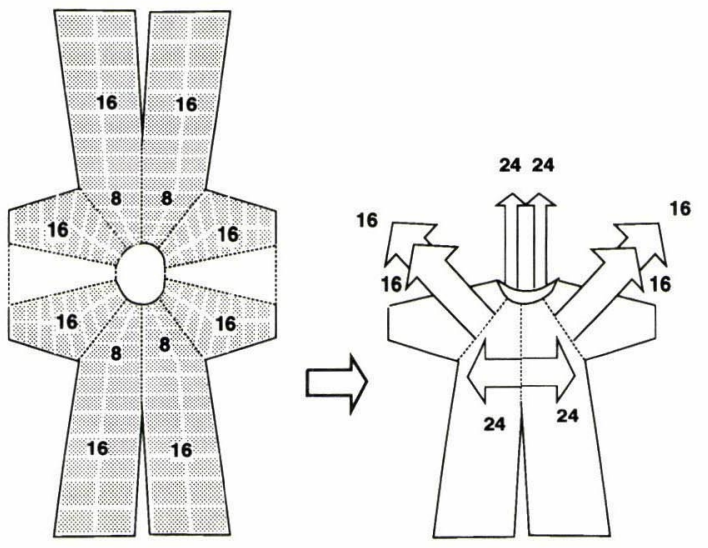

Fig. 9 Structure of the sensor suit for the full-body humanoid

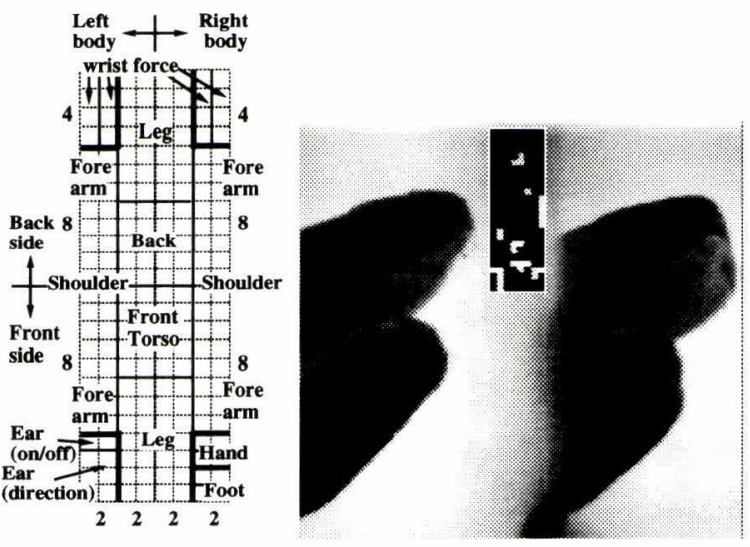

Fig. 10 The sensor image map of the sonsor suit and an example superimposed on a stereo image of the robot vision
そでから各 16 ずつ帯状に取り出しており，小型スナップで電 子回路に接続している。一つの接触領域の大きさは，身頃部分

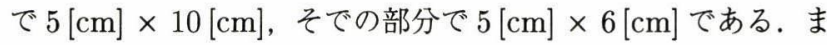
た，センサスーツ全体の重さは $1.15[\mathrm{~kg}]$ ，また背中に背負わせ たインターフェース回路部が $350[\mathrm{~g}]$ で，システムとして合計 $1.5[\mathrm{~kg}]$ になった

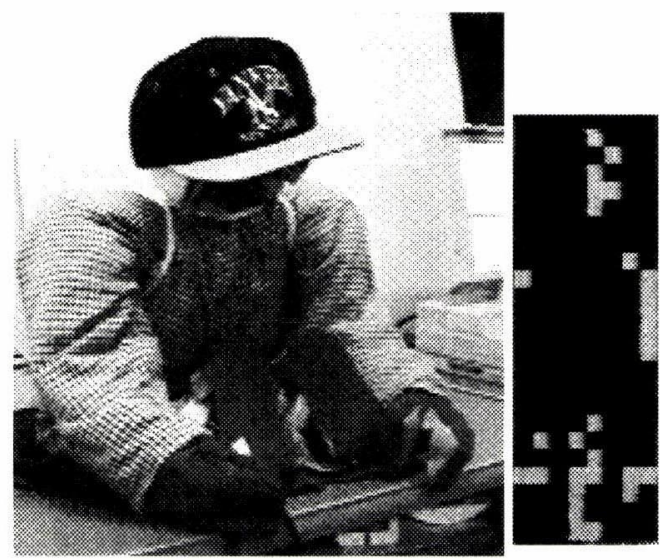

Fig. 11 Sensor image of the initial stage

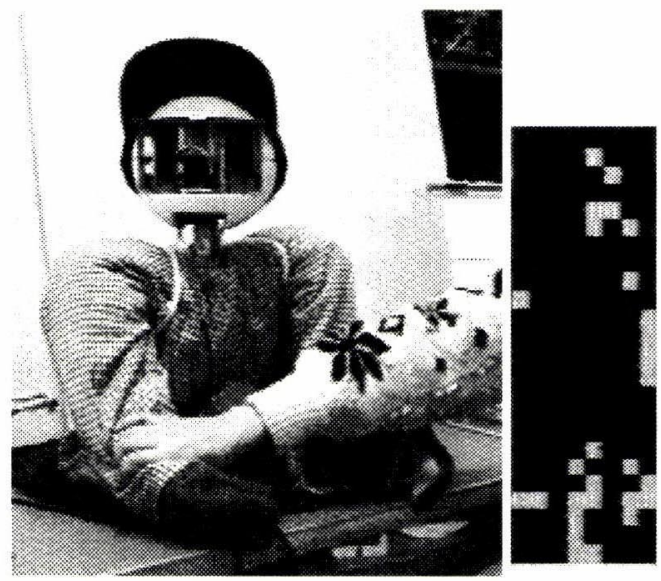

Fig. 12 Reaction (1): when the humanoid is touched on the right fore arm

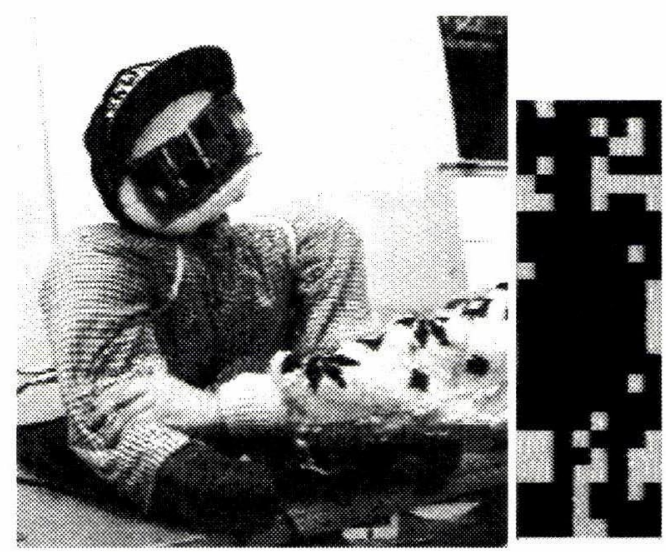

Fig. 13 Reaction (2): when the human holds the both arms of the humanoid 


\section{2 接触情報の画像化}

センサスーツの接触情報は, 導電性の糸からスナップによる コネクタを通して, 画像化ハードウェアによってロボットのカ メラ画像上に多重化される。この多重化は, ビデオ信号の夕 イミングに従って, 複数のセンサを順次走査し, カメラのビデ オ信号とをアナログスイッチによって切り替えることで行われ る [10].

センサスーツの接触デー夕とそれ以外のセンサ情報もまとめ て重畳表示するために, 画面中央に横 8 行縦 24 列という領域 に対応関係が分かりやすい形状と配置の表示部を設けた．実際 のボディ上の部位との対応関係と多重化されている画像全体の 例を Fig. 10 に示す.

Fig. 11 に，なにも触られていないときのロボットの状態と センサ画像部のパターンを示す. 図中白いドットはセンサデー 夕 ON になっている箇所である，座っているために警部の部 分は ONになっている．また，画像化回路を入れたショルダー バックを背負っているために肩部も ON になっている．人間が ロボットの右腕または両腕をつかんだときは Fig. 12, Fig.13 のようにセンサ画像パターンが変化する，何も触られていない 状態から, センサ画像パターンの時間的変化に着目することで, その変化に応じた対応行動をとる実験に成功している.

\section{7. 結論と今後の課題}

人間の生活空間に入り込むことが求められているロボットに 対して，直接ロボットに触れることができ，ロボットもそれを 感じることができる機能を実現するために全身に触覚を分布さ せる方法として, 布構造をもつ導電性ファブリックを用いた口 ボット用センサスーツを開発し，その評価実験について述べた．

用いた導電性の布と系は, 化学メッキによって薄くかつ均質 に䄉維内部まで金属をメッキすることによってできあがったも のであり，折れ曲がりや湿度に対して剥がれが拉きにくい素材 となっている. やわらかさも通常の布や系と変わりなく, プラ スチックフィルムや金属線で作った場合に比べて格段に柔軟性 と多数のセンサユニット配線が可能となる.

本センサスーツの構成法は，衣服製作と同じ方式で製作でき るため，ロボットの形態によらず，様々な形に対応可能である. ロボットにかぎらず，人間用のスーッや，人間が触れる人工物
の表面にかぶせることで，接触情報を取り出す入力デバイスと して利用することが可能な構成法となっている.

一方，ロボットが着ていて関節を曲げた場合にできるしわに よってセンサが ONになり，外部との接触によるものか内部の 動きによるものかの区別はこのセンサスーツの情報からだけで は判断できない。しかし，自らの動きのない状態からの時間変 化具合を利用したり，自らの動き情報と組み合わせて判断した り，視覚などの他のセンサを利用するなどの複合的センサ情報 処理を行うことによって対応させれば，全身にセンサを分布し 着せ替え可能な特長を有効に利用することができると考えられ， その処理方法については今後の課題である.

\section{参 考 文 献}

[1] Makoto Shimojo, Shigeru Sato, Yoshikazu Seki and Akihiko Takahashi: "A system for simultaneous measuring grasping posture and pressure distribution," In IEEE International Conference on Robotics and Automation, pp.831-836, 1995.

[2] 山田陽磁, 西誠治, 水口尚宏, 黄声揚, 梅谷陽二：“動的触覚イメー ジャ”, 第 13 回日本ロボット学会学術講演会, pp.941-942, 1995.

[3] Shigeru Ando Hiroyuki Shinoda: "Ultrasonic emission tactile sensor for contact localization and characterization," In IEEE International Conference on Robotics and Automation, pp.2536-2543, 1994.

[4] Howard R. Nicholls and Mark H. Lee: "A survey of robot tactile sensing technology," The International Journal of Robotics Research, vol.8, no.3, pp.3-30, 6, 1989.

５］新和久, 山田陽磁, 土田縫夫, 駒井又二：“回転関節部触覚センサの 開発”, 第 7 回日本ロボット学会学術講演会, pp.575-576, 1989.

[6] Edward Cheung and Vladimir Lumelsky: "Development of sensitive skin for a 3 rd robot arm operating in an uncertain environment," In IEEE International Conference on Robotics and Automation, pp.1056-1061, 1989.

[7] Yoji Yamada, Kazuhisa Shin, Nuio Tsuchida and Mataji Komai: "A tactile system for universal joint section of manipulaters," IEEE Transaction on Robotics and Automation, vol.9, no.4, pp.512-517, 1993.

[ 8 ] 下条誠, 石川正俊: “薄型フレキシブル位置覚センサとその応用”, 計 測自動制御学会論文集, vol.21, no.11, pp.114-116, 11, 1985.

[9] 五十嵐貴, 稲葉雅幸, 井上博允：“35 自由度を有する人間型ロボット の開発”, 日本ロボット学会第 12 回学術講演会予稿集, pp.309-310, 1994.

[10］長阪憲一郎, 加賀美聡, 稲葉雅幸, 井上博允: “リモートブレインロボッ トにおけるビデオ信号へのスーパーインポーズを利用したセンサフィー ドバック”, 第 13 回日本ロボット学会学術講演会, pp.1025-1026, 1995.

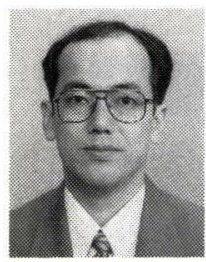

稲葉雅幸（Masayuki Inaba）

1958 年 5 月 23 日生. 1986 年東京大学大学院工学 系研究科情報工学専門課程博士課程修了. 工学博 士. 1989 年東京大学工学部機械情報工学科助教授, 現在に至る. 日本機械学会, 情報処理学会, 計測自 動制御学会, 人工知能学会会員.

(日本ロボット学会正会員)

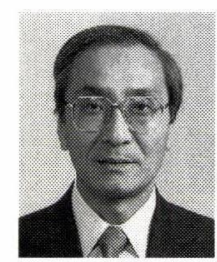

井上博允 (Hirochika Inoue)

1942 年 7 月生. 1965 年東京大学工学部産業機械 工学科卒業. 1970 年同大学院博士課程修了. 工学 博士. 同年電子技術総合研究所入所. 1977 年東京 大学工学部機械工学科助教授. 1984 年教授. 現在, 機械情報工学科教授、ロボット全般, 人工知能, 情 報システム工学の研究と教育に従事.

(日本ロボット学会正会員)

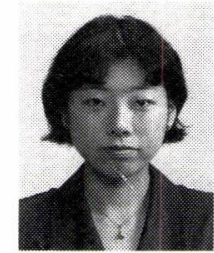

星野由紀子 (Yukiko Hoshino)

1973 年 5 月 2 日生. 1996 年東京大学工学部機械情 報工学科卒業. 現在, 同大学大学院修士課程在学 中. 日常生活に入っていけるロボットの研究に興味 を持つ. 1996 年度研究奖励賞受賞. 日本機械学会 学生会員.

(日本ロボット学会学生会員) 